\title{
Molecular targets for therapy in systemic sclerosis
}

\author{
Naoki Iwamoto, Oliver Distler ${ }^{*}$ \\ From Fibroproliferative disorders: from biochemical analysis to targeted therapies \\ Frauenchiemsee, Germany. 25-30 September 2010
}

\begin{abstract}
Despite significant advances have been made in the recent years regarding organ-specific therapies, there is no approved 'disease-modifying' antifibrotic drug for systemic sclerosis (SSc) available to date. Although non-selective immunosuppressive agents are routinely used to treat patients with SSc, large well-controlled studies are lacking for almost all immunosuppressive agents and further evidence is required for long-term beneficial effects of these drugs. Considering these facts about immunosuppressive agents in SSC and also considering the high mortality of SSC, other therapeutic strategies are urgently needed. Recently an important role of the 5-hydroxytryptamine (5-HT: serotonin) pathway in fibrosis was reported. In this review, we discuss the role of 5-HT in fibrosis and therapeutic potential of this molecule. Besides 5-HT, there are a number of promising targets that have been extensively characterized in recent years. For many of these molecular targets, modifiers are readily available for clinical studies, and often these modifiers are used already in clinical use for other diseases. Results from these studies will show, in how far the promising preclinical results for novel antifibrotic strategies can be translated to clinical practice.
\end{abstract}

\section{Introduction}

Systemic sclerosis $(\mathrm{SSc})$ is a multisystem connective tissue disease that is characterized by fibrosis of the skin and internal organs and also by widespread vasculopathy. Clinical manifestations include thickening of the skin, Raynaud's phenomenon, pulmonary arterial hypertension, pulmonary fibrosis and involvement of other visceral organs [1]. Histological hallmarks in the skin of early stage of SSc are perivascular inflammatory infiltrates and microvascular changes such as capillary dilatation with subsequent rarefaction. In later stage, this leads to tissue fibrosis with an excessive accumulation of extracellular matrix $[2,3]$. Tissue fibrosis disrupts the physiological tissue architecture and causes dysfunction of the affected organs. Organ dysfunction can lead to organ failure and contributes profoundly to the increased mortality of SSc. Despite intensive research, lack of evidence for the treatment of SSc patients complicates the appropriate management of SSc patients.

Although its etiology still remains unknown, knowledge about the pathogenesis of SSc is rapidly increasing. Significant progress has been achieved in the identification of

\footnotetext{
* Correspondence: Oliver.Distler@usz.ch

Department of Rheumatology, Center of Experimental Rheumatology, University Hospital Zurich, Gloriastrasse 25, 8091 Zürich, Switzerland
}

possible molecular targets for therapy in SSc. In this article, we will summarize current therapeutic approaches using immunosuppressive agents in SSc, discuss limitations of such approaches and focus on novel molecular targets for therapy to treat fibrotic manifestations by using the 5-hydroxytryptamine (5-HT: serotonin) pathway as an example.

\section{Current therapy for SSc}

Significant advances have been made in the recent years regarding symptomatic organ-specific therapies [4]. However, there is no approved 'disease-modifying' drug for SSc that modifies the fibrotic manifestations of the disease.

Non-selective immunosuppressive agents are routinely used to treat patients with SSc. A recent report from the German SSc registry showed that $41 \%$ patients received corticosteroids and $36 \%$ received immunosuppressive agents [5]. Despite their frequent use, there is only limited data on their efficacy in SSc and only few controlled clinical studies have been performed for nonselective immunosuppressive agents. The low prevalence of SSc, various disease subsets and a highly variable course of the disease are making it difficult to perform welldesigned clinical studies with a significant number of patients [6]. Table 1 summarizes the main randomized 
Table 1 Randomized controlled trials evaluating immunosuppressive/immunomodulatory drugs in patients with SSc.

\begin{tabular}{|c|c|c|c|c|}
\hline Reference & Treatment & $\begin{array}{l}\text { Number and main } \\
\text { inclusion criteria of SSC } \\
\text { patients }\end{array}$ & $\begin{array}{l}\text { Study } \\
\text { duration }\end{array}$ & Clinical effect \\
\hline $\begin{array}{l}\text { Furst DE et al. } \\
\text { Arthritis } \\
\text { Rheum } \\
\text { 1989;32:584 }\end{array}$ & Chlorambucil p.o. 0.05-0.1 mg/kg/day versus placebo & 65 SSC & 3 years & NS effect \\
\hline $\begin{array}{l}\text { O'Dell JR et al. } \\
\text { J Rheumatol } \\
\text { 1989;32:584 }\end{array}$ & Total lymphoid irradiation versus untreated control & $\begin{array}{l}6 \text { SSC with internal organ } \\
\text { involvement }\end{array}$ & $\begin{array}{l}\text { Follow- } \\
\text { up of } 1- \\
4 \text { years }\end{array}$ & NS effect \\
\hline $\begin{array}{l}\text { Casaes JA et } \\
\text { al. } \\
\text { Ann Rheum } \\
\text { Dis } \\
\text { 1990;49:926 }\end{array}$ & $\begin{array}{l}\text { 5-fluorouracil i.v. } 4 \times 12 \mathrm{mg} / \mathrm{kg} \text { daily, followed by } 4 \\
\times 6 \mathrm{mg} / \mathrm{kg} \text { every two days and maintenance } \\
\text { therapy with } 12.5 \mathrm{mg} / \mathrm{kg} \text { weekly versus placebo }\end{array}$ & $\begin{array}{l}70 \text { SSC (diffuse or limited } \\
\text { with visceral involvement) }\end{array}$ & $\begin{array}{l}6 \\
\text { months }\end{array}$ & $\begin{array}{l}\text { Significant improvement in skin score, } \\
\text { Raynaud's score and patient's general } \\
\text { assesment scores }\end{array}$ \\
\hline $\begin{array}{l}\text { Sharada B et } \\
\text { al. } \\
\text { Rheumatol Int } \\
1994 ; 14: 91\end{array}$ & Dexamethasone i.v. $100 \mathrm{mg} / \mathrm{month}$ versus placebo & 35 diffuse SSC & $\begin{array}{l}6 \\
\text { months }\end{array}$ & Significant improvement in skin score \\
\hline $\begin{array}{l}\text { Van den } \\
\text { Hoogen } \mathrm{FH} \text { et } \\
\text { al. } \\
\mathrm{Br} J \\
\text { Rheumatol } \\
\text { 1996;35:364 }\end{array}$ & Methotrexate i.m. 15 mg/week versus placebo & $\begin{array}{l}29 \text { SSC with }<3 \text { years of } \\
\text { skin involvement or with } \\
\text { disease progression }\end{array}$ & $\begin{array}{l}24 \\
\text { weeks }\end{array}$ & $\begin{array}{l}\text { Trend towards improvement in skin } \\
\text { score }(p=0.06 \text { in comparison with } \\
\text { placebo) }\end{array}$ \\
\hline $\begin{array}{l}\text { Clements PJ } \\
\text { et al. Arthritis } \\
\text { Rheum } \\
\text { 2001;44:1351 }\end{array}$ & $\begin{array}{l}\text { D-penicillamine p.o. high ( } 750-1000 \mathrm{mg} / \mathrm{d} \text { ) versus } \\
\text { low ( } 125 \mathrm{mg} \text { every second day) dose }\end{array}$ & 134 early diffuse SSC & 2 years & NS effect \\
\hline $\begin{array}{l}\text { Pope JE et al. } \\
\text { Arthritis } \\
\text { Rheum } \\
2001 ; 44: 1351\end{array}$ & Methotrexate p.o. 15 mg/week versus placebo & 71 early diffuse SSC & 1 year & $\begin{array}{l}\text { Improvement in skin scores, borderline } \\
\text { significance }\end{array}$ \\
\hline $\begin{array}{l}\text { Tashkin DP et } \\
\text { al. N Eng J } \\
\text { Med } \\
\text { 2006;354:2655 }\end{array}$ & Cyclophosphamide p.o. 1-2 mg/kg/d versus placebo & $\begin{array}{l}154 \text { SSC with early ( }<7 \\
\text { years duration) SSC, } \\
\text { symptomatic SLD and } \\
\text { alveolitis }\end{array}$ & 1 year & $\begin{array}{l}\text { Significant improvement in lung } \\
\text { volumes, dyspnoea and some } \\
\text { measures of health related quality of } \\
\text { life. } \\
\text { Significant improvement in skin score } \\
\text { in diffuse SSc as a secondary outcome } \\
\text { measure }\end{array}$ \\
\hline $\begin{array}{l}\text { Hoyles Rk et } \\
\text { al. } \\
\text { Arthritis } \\
\text { Rheum } \\
\text { 2006;54:3962 }\end{array}$ & $\begin{array}{l}\text { Cyclophosphamide } 6 \times \text { i.v. } 600 \mathrm{mg} / \mathrm{m}^{2} / \mathrm{month} \text { plus } \\
\text { oral predonisone } 20 \mathrm{mg} \text { every second day followed } \\
\text { by azathioprine (p.o. } 2.5 \mathrm{mg} / \mathrm{kg} / \text { day) versus placebo }\end{array}$ & 45 SSC with SLD & 1 year & $\begin{array}{l}\text { Trend towards improvement of FVC ( } p \\
=0.08) \text {, but low power }\end{array}$ \\
\hline $\begin{array}{l}\text { Nadashkevich } \\
\text { O et al. } \\
\text { Clin }\end{array}$ & $\begin{array}{l}\text { Cyclophosphamide p.o. } 2 \mathrm{mg} / \mathrm{kg} / \mathrm{d} \text { for } 12 \text { months, } \\
\text { then } 1 \mathrm{mg} / \mathrm{kg} / \mathrm{d} \text { for another } 6 \text { months versus } \\
\text { asathioprine } 2.5 \mathrm{mg} / \mathrm{kg} / \mathrm{d} \text { for } 12 \text { months and then } 2\end{array}$ & $\begin{array}{l}60 \text { early diffuse SSC }(<12 \\
\text { months duration) }\end{array}$ & $\begin{array}{l}18 \\
\text { months }\end{array}$ & $\begin{array}{l}\text { Significant improvement in skin score, } \\
\text { lung function tests and frequency of } \\
\text { attacks of Raynaud's phenomenon }\end{array}$ \\
\hline
\end{tabular}

i.v. = intravenous, i.m. = intramuscular, p.o. = peroral, NS = not significant, SLD = scleroderma interstitial lung diseases, SSc = systemic sclerosis. This list is not complete and is only a selection of potential molecules for targeted therapies. Modified from Distler O: Screloderma-modern aspects of pathogenesis, diagnosis and therapy. UNI-MED 2009.

controlled trials (RCTs) that have been performed to date.

Although there is clinical evidence that corticosteroid treatment is effective for some clinical manifestations that can occur in association with SSc such as inflammatory arthritis and myositis, use of higher dose corticosteroids is not recommended in SSc except for certain treatment-resistant and severe cases. The reason for this recommendation is that several retrospective case-control studies revealed that corticosteroid doses with a prednisone equivalent of more than $15 \mathrm{mg} /$ day increased significantly the risk of developing scleroderma renal crisis, which is a severe and life threatening disease manifestation of SSc $[7,8]$.

Large well-controlled studies are lacking for almost all immunosuppressive agents that are used in SSc. 
However, few randomized RCTs for immunosuppressive therapies are available. A beneficial effect on skin fibrosis was shown for methotrexate, 5-fluorouracyl, oral cyclophosphamide and intravenous dexamethasone. This effect was mainly seen in patients with diffuse SSc and the effects were small. It is questionable whether these effects are clinically meaningful. Beneficial effects on internal organ involvement were only seen in patients with scleroderma lung disease treated with oral cyclophosphamide showing improved lung volumes and dyspnoea scores compared to placebo. Again, the observed effects were small, and all effects seen with cyclophosphamide treatment, except for sustained improvement in patient-reported dyspnoea, waned within 12-18 months after stopping therapy [9]. Several other immunosuppressive medications including mycophenolate mofetil, anti-thymocyte globulin, azathioprine, cyclosporine, intravenous immunogloblins or combination of cyclophosphamide with high dose corticosteroids have shown some efficacy in small open-label, uncontrolled studies or retrospective analyses, but well-performed RCTs are not available.

In summary, small observational trials, case reports and a limited number of RCTs suggested some efficacy of immunosuppressive agents. Thus, an immunosuppressive therapeutic approach may be considered in early inflammatory stages of diffuse SSc. However, further evidence is required for long-term beneficial effects of these drugs. In addition, the observed effects in clinical trials were often small, which also reflects the experience in clinical practice. The potential toxicity of immunosuppressive treatments also needs to be included in a risk/benefit analysis and may limit long-term usage of these treatments in SSc. Considering the high mortality of SSc secondary to fibrotic manifestations, other therapeutic approach are urgently needed for SSc.

\section{Novel therapeutic target for fibrosis in SSc}

Indeed, significant inflammatory infiltrates in the skin are often limited to very early disease stages, and even in these early disease stages meaningful infiltrates can only be found in perivascular areas. There is also increasing evidence that the molecular expression pattern in SSc skin is extremely heterogeneous, and that only smaller subsets of patients express increased levels of inflammatory molecules [10]. Thus, unselective immunosuppressives might be useful for smaller subsets of SSc patients, while the large majority of patients might need different therapeutic approaches. In this regard, mechanisms leading to the increased synthesis of extracellular matrix proteins in fibroblasts are of particular interest for targeted therapies.

Remarkable breakthrough findings have been obtained regarding the identification of key molecules, key cellular mechanisms, and key intracellular signaling cascades, which mediate the perpetuation of fibrosis. These findings have true translational implications, because the modifiers of these key mediators and key mechanisms are often in clinical use in other diseases such as cancer. Among these key molecules, recent reports showed an important role of the 5-hydroxytryptamine (5-HT: serotonin) pathway in fibrosis [11]. Here, we focus on the serotonin pathway as a novel target in the treatment of SSc and summarize these recent results as an example for a preclinical characterization of molecular targets in SSc.

Microvascular damage is one of the earliest features in the pathogenesis of SSc leading to a progressive loss of capillaries [12]. Microvascular injury precedes clinically detectable tissue fibrosis in SSc. However, molecular links between microvascular damage and the induction of tissue fibrosis have not been established. One possible link could be 5 -HT, because the microvascular damage with exposure of subendothelial connective tissue activates platelets and activated platelets release large amounts of 5-HT. Based on these considerations and the fact that $5-\mathrm{HT}$ is elevated in the blood of SSc patients [13-15], we hypothesized that 5-HT signaling might be involved in the process of fibrosis in SSc [11].

First, we investigated, whether 5 -HT is able to induce the release of extracellular matrix proteins in SSc. Primary dermal fibroblasts from SSc patients and healthy subjects, which were stimulated with 5 -HT, increased the mRNA of different extracellular matrix proteins such as collagen type I alpha 1 (COL1A1), collagen type I alpha 2 (COL1A2) and fibronectin-1 in dose-dependent manner. Similarly, the release of collagen protein was also increased by 5 -HT stimulation. Doses used for the stimulations were in the range of those detected in biological fluids.

There are seven 5-HT receptors, 5-HT1 to 5-HT7, and the cellular effects of $5-\mathrm{HT}$ are mediated by these receptors. The identification of those receptors, which play a crucial role in fibrosis, was necessary, because receptor antagonists often show more efficacy and safety than ligand antagonist. Thus, we next investigated, which receptor specifically mediates the profibrotic effects of 5-HT. We observed that three different 5-HT receptors were expressed by dermal fibroblasts: $5-\mathrm{HT}_{1 \mathrm{~B}}$, $5-\mathrm{HT}_{2 \mathrm{~A}}$, and $5-\mathrm{HT}_{2 \mathrm{~B}}$. The mRNA levels of $5-\mathrm{HT}_{2 \mathrm{~B}}$ were up regulated in SSc fibroblasts as compared with healthy controls $(143 \pm 17 \%)$, while $5-\mathrm{HT}_{1 \mathrm{~B}}$ and $5-\mathrm{HT}_{2 \mathrm{~A}}$ were not different. Inhibition of 5 -HT1 by selective chemical inhibitors showed no reduction of the stimulatory effects of 5-HT on extracellular matrix production in SSc fibroblasts. In contrast, inhibition of 5-HT2 decreased mRNA levels of COL 1A1, COL 1A2 and fibronectin-1 and also decreased the release of collagen protein. Additional inhibition experiments using chemical inhibitors as well as siRNA approaches revealed that this effect 
was specific for $5-\mathrm{HT}_{2 \mathrm{~B}}$, but not for $5-\mathrm{HT}_{2 \mathrm{~A}}$. These results suggested that $5-\mathrm{HT}_{2 \mathrm{~B}}$ plays crucial role for the synthesis of extracellular matrix proteins in dermal fibroblasts.

Immunohistochemistry in fibrotic skin biopsies of SSc patients and normal skin of healthy individuals backed up these results. Expression of 5- $\mathrm{HT}_{2 \mathrm{~B}}$ was strongly increased in fibrotic tissue as compared with unaffected tissue from healthy controls. Double staining with the fibroblast-specific marker prolyl-4-hydroxylase-beta confirmed that $5-\mathrm{HT}_{2 \mathrm{~B}}$ was mostly expressed by dermal fibroblasts, and the large majority of fibroblasts stained positive for $5-\mathrm{HT}_{2 \mathrm{~B}}$ in fibrotic tissue, but not in controls.

The profibrotic effects of $5-\mathrm{HT} / 5-\mathrm{HT}_{2 \mathrm{~B}}$ could be mediated via direct increase of collagen mRNA transcription or indirectly via induction of a second mediator. We suspected indirect mechanisms, because the effects of 5 -HT in the COL1A2 reporter assay were delayed compared to the effects of transforming growth factor- $\beta$ (TGF- $\beta$ ), which is a well known key player in the pathogenesis of fibrosis [16]. Thus, we investigated, whether TGF- $\beta$ itself might be the second mediator of 5-HT signalling. Interestingly, 5-HT increased dose-dependently mRNA levels of TGF- $\beta 1$ in SSc fibroblasts. Furthermore, 5 -HT induced in a time-dependent manner the nuclear levels of phospho-Smad3, the typical intracellular mediator of TGF- $\beta$ signalling. To evaluate whether TGF- $\beta$ is necessary for the profibrotic effect of $5-\mathrm{HT}$, we cultured SSc fibroblasts with neutralizing antibodies against TGF$\beta 1$. Inhibition of TGF- $\beta 1$ completely abrogated the profibrotic effects of 5-HT on mRNA expression of COL1A1, COL $1 \mathrm{~A} 2$ and fibronectin-1.

Next, we aimed to demonstrate that these in vitro results reflect in vivo situations by using the mouse model of bleomycin-induced dermal fibrosis. Injection of bleomycin potently stimulated the expression of $5-\mathrm{HT}_{2 \mathrm{~B}}$ and induced dermal fibrosis. The 5-HT2 inhibitors terguride and cyproheptadine as well as the selective $5-\mathrm{HT}_{2 \mathrm{~B}}$ inhibitor $\mathrm{SB}$ 204741 [17-20] efficiently prevented bleomycine-induced dermal thickening. Collagen content and myofibroblast counts were also reduced dose-dependently by inhibition of $5-\mathrm{HT}_{2 \mathrm{~B}}$. The antifibrotic effects of 5-HT2 inhibition were further tested in a therapeutic approach using a modification of the bleomycin model. Dermal thickening decreased by $78 \pm 4 \%$ in mice treated with terguride for the last 3 weeks compared with placebo treated mice. Finally, we used $5-\mathrm{HT}_{2 \mathrm{~B}}$-deficient mice to confirm the role of $5-\mathrm{HT}_{2 \mathrm{~B}}$ in experimental fibrosis. $5-\mathrm{HT}_{2 \mathrm{~B}}{ }^{-1-}$ mice were almost completely protected from bleomycininduced dermal fibrosis, although no spontaneous histological changes or differences in dermal thickness were observed in untreated $5-\mathrm{HT}_{2 \mathrm{~B}}{ }^{-1-}$ mice.

There is no single animal model that completely covers the different aspects in the pathogenesis of SSc [21].
For example, in the bleomycin model, fibrosis is triggered by intense inflammatory infiltrates in the skin. As outlined above, inflammatory infiltrates are present in early inflammatory stages of human SSc, but are not a feature of later disease stages. Thus, for the identification of potential molecular targets for therapy, testing in at least one additional model is recommended [22]. We therefore assessed the role of $5-\mathrm{HT}_{2 \mathrm{~B}}$ in a less inflammation-dependent mouse model of fibrosis, the tight skin 1 (Tsk-1) model. As in human SSc and experimental bleomycin-induced fibrosis, $5-\mathrm{HT}_{2 \mathrm{~B}}$ was overexpressed in skin sections of Tsk-1 mice. Hypodermal thickening, collagen content, and differentiation of resting fibroblasts into myofibroblasts were significantly reduced in Tsk-1 mice upon treatment with the $5-\mathrm{HT}_{2 \mathrm{~B}}$ inhibitor SB 204741. Similarly, Tsk-1 mice crossed with $5-\mathrm{HT}_{2 \mathrm{~B}}{ }^{-1-}$ mice showed reduced hypodermal thickening, reduced collagen content, and decreased numbers of myofibroblasts compared with TSk-1 mice crossed with $5-\mathrm{HT}_{2 \mathrm{~B}}{ }^{+/+}$mice.

To confirm the link between platelet activation and increased 5- $\mathrm{HT} / 5-\mathrm{HT}_{2 \mathrm{~B}}$ signalling, we examined whether inhibition of platelet activation reduces tissue levels of 5HT and prevents experimental fibrosis. Indeed, treatment with the $\mathrm{P}_{2} \mathrm{Y}_{12}$ receptor inhibitor clopidogrel reduced the content of 5-HT in fibrotic skin of bleomycin-challenged mice by $58 \pm 21 \%$. In parallel, clopidogrel decreased dermal thickening by $61 \pm 13 \%$ as compared with control mice. This was also seen in Tsk-1 mice experiments, in which treatment with clopidogrel reduced hypodermal thickening by $51 \pm 16 \%$.

Tryptophan hydroxylase (TPH) 1 is the key enzyme for the synthesis of 5-HT in platelets. Experiments with TPH 1 deficient mice further underlined the important role of platelet-derived 5-HT in experimental fibrosis. Blood levels of $5-\mathrm{HT}$ in $\mathrm{TPH} 1^{-1-}$ mice were reduced to $5 \%$ compared with wild-type animals [23]. Dermal thickening in bleomycin-challenged $\mathrm{TPH} 1^{-1-}$ mice were decreased by $61 \pm 6 \%$ as compared with bleomycinchallenged $\mathrm{TPH} 1^{+/+}$mice. Similarly, collagen content and myofibroblast counts were significantly reduced.

\section{Conclusion}

These data provide circumstantial evidence for 5-HT/5$\mathrm{HT}_{2 \mathrm{~B}}$ signalling as a potential therapeutic target in SSc. They also provide a template for an extended pre-clinical characterization of other potential therapeutic targets in fibrotic diseases such as SSc. Indeed, there are a number of promising targets that have been extensively characterized in recent years, and $5-\mathrm{HT} / 5-\mathrm{HT}_{2 \mathrm{~B}}$ is just one example among them. Table 2 gives an overview of potential targets for therapy in SSc. Most interestingly, for many of these molecular targets, modifiers are readily available for clinical studies, and often these modifiers are used 
Table 2 Possible molecular targets for therapy in SSc

\begin{tabular}{|c|c|c|}
\hline Target molecules & Available drug name & References \\
\hline Tyrosine kinases & Imatinib, Nilotinib, Dasatinib & $\begin{array}{l}\text { Iwamoto N et al. } \\
\text { Curr Rheumatol Rep. } \\
\text { 2011;13:21 }\end{array}$ \\
\hline SRC kinases & SU6656, Dasatinib & $\begin{array}{l}\text { Akhmetshina A et al. } \\
\text { FASEB J. } \\
\text { 2008;22:2214 }\end{array}$ \\
\hline TGF-b inhibitors & Several drugs & $\begin{array}{l}\text { Asano Y. } \\
\text { J Dermatol } \\
\text { 2010;37:54 } \\
\end{array}$ \\
\hline Histondeacetylase inhibitor & Trichostatin, SAHA & $\begin{array}{l}\text { Huber LC et al. } \\
\text { Arthritis Rheum } \\
\text { 2007;56:2755 }\end{array}$ \\
\hline DNA Methyltransferase inhibitors & $5-A Z A$ & $\begin{array}{l}\text { Wang Y et al. } \\
\text { Arthritis Rheum } \\
\text { 2006;54:2271 }\end{array}$ \\
\hline Rho associated kinase & Fasudil & $\begin{array}{l}\text { Akhmetshina A et al. } \\
\text { Arthritis Rheum } \\
\text { 2008;58:2553 }\end{array}$ \\
\hline Cannabinoid receptor 2 (CB2) agonists & Several drugs & $\begin{array}{l}\text { Akhmetshina A et al. } \\
\text { Arthritis Rheum. } \\
\text { 2009;60:1129 }\end{array}$ \\
\hline PPAR $\gamma$ agonists & None & $\begin{array}{l}\text { Wei J et al. } \\
\text { PloS One } \\
\text { 2010;5:e13778 }\end{array}$ \\
\hline Adenosine $\mathrm{A} 2 \mathrm{~A}$ receptor blockers & None & $\begin{array}{l}\text { Chan ES et al. } \\
\text { Arthritis Rheum. } \\
\text { 2006;54:2632 }\end{array}$ \\
\hline IL-13 inhibitors & None & $\begin{array}{l}\text { Lafyatis R et al. } \\
\text { Endocr Metab Immune Disord Targets } \\
\text { 2006;6:395 }\end{array}$ \\
\hline Serotonin-Receptor-2B inhibitors & Terguride & $\begin{array}{l}\text { Dees C et al. } \\
\text { J Exp Med. } \\
\text { 2011; 208:961 }\end{array}$ \\
\hline CTGF inhibitor & CTGF antibodies & $\begin{array}{l}\text { Wang Q et al. } \\
\text { Fibrogenesis Tissue Repair } \\
\text { 2011;4:4 }\end{array}$ \\
\hline IL-6 receptor antagonist & Tocilizmab & $\begin{array}{l}\text { Shima Y et al. } \\
\text { Rheumatology(oxford) } \\
\text { 2010;49:2408 }\end{array}$ \\
\hline MicroRNA-29a & None & $\begin{array}{l}\text { Maurer B et al. } \\
\text { Arthritis Rheum } \\
\text { 2010;62:1733 }\end{array}$ \\
\hline Fos-Related Antigen-2 (AP-1 family) & None & $\begin{array}{l}\text { Reich N et al. } \\
\text { Arthritis Rheum } \\
\text { 2010;62:280 } \\
\text { Maurer B et al. } \\
\text { Circulation. } \\
\text { 2009;120:2367 }\end{array}$ \\
\hline
\end{tabular}

already in clinical practice for other diseases. The 5-HT inhibitor terguride is approved in Japan for the treatment of hyperprolactinemia and is currently tested in a proof of concept trial in patients with SSc. This study has finished recruitment and is currently awaiting analysis. This and similar studies will show, in how far the extended preclinical characterization outlined above is able to predict clinical responses in human fibrotic diseases such as SSc.
List of abbreviations used

SSc: Systemic sclerosis; RCTs: randomized controlled trials; 5-HT: 5hydroxytryptamine; COL1A1: collagen type I alpha 1; COL1A2: collagen type I alpha 1; TGF- 3 transforming; Tsk-1: tight skin 1; TPH: tryptophan hydroxylase.

\section{Acknowledgements}

This article has been published as part of Fibrogenesis \& Tissue Repair Volume 5 Supplement 1, 2012: Proceedings of Fibroproliferative disorders: from biochemical analysis to targeted therapies. The full contents of the supplement are available online at http://www.fibrogenesis.com/ supplements/5/S1. 


\section{Competing interests}

Dr. O. Distler has received consulting fees and/or research grants from Pfizer, Actelion, Encysive, FibroGen, Ergonex, NicOX, Bristol-Myers Squibb, SanofiAventis, United BioSource, Medac, Biovitrium and Active Biotech with regard to potential scleroderma treatments.

Published: 6 June 2012

\section{References}

1. Distler O, Gay S: [Scleroderma]. Internist(Berl) 2010, 51:30-38.

2. Gabrielli A, Avvedimento EV, Krieg T: Scleroderma. N Engl JMed 2009, 360:1989-2003.

3. Abraham DJ, Krieg T, Distler J, Distler O: Overview of pathogenesis of systemic sclerosis. Rheumatology (Oxford) 2009, 48(Suppl 3):iii3-7.

4. Denton CP, Black CM: Scleroderma - clinical and pathological advances. Best Pract Res Clin Rheumatol 2004, 18:271-290.

5. Hunzelmann N, Moinzadeh P, Genth E, Krieg T, Lehmacher W, Melchers I, Meurer M, Müller-Ladner U, Olski TM, Pfeiffer C, Riemekasten G, SchulzeLohoff E, Sunderkoetter C, Weber M, German Network for Systemic Scleroderma Centers: High frequency of corticosteroid and immunosuppressive therapy in patients with systemic sclerosis despite limited evidence for efficacy. Arthritis Res Ther 2009, 11:R30.

6. White B, Bauer EA, Goldsmith LA: Guidelines for clinical trials in systemic sclerosis (scleroderma). I. Disease modifying interventions. The American College of Rheumatology Committee on Design and Outcomes in Clinical Trials in Systemic sclerosis. Arthritis Rheum 1995, 38:351-360.

7. Steen VD, Medsger TA Jr: Case-control study of corticosteroids and other drugs that either precipitate or protect from the development of scleroderma renal crisis. Arthritis Rheum 1998, 41:1613-1619.

8. Steen VD, Medsger TA Jr: Long-term outcomes of scleroderma renal crisis. Ann Intern Med 2000, 133:600-603.

9. Tashkin DP, Elashoff R, Clements PJ, Roth MD, Furst DE, Silver RM, Goldin J, Arriola E, Strange C, Bolster MB, Seibold JR, Riley DJ, Hsu VM, Varga J, Schraufnagel D, Theodore A, Simms R, Wise R, Wigley F, White B, Steen V, Read C, Mayes M, Parsley E, Mubarak K, Connolly MK, Golden J, Olman M, Fessler B, Rothfield N, et al: Effects of 1-year treatment with cyclophosphamide on outcomes at 2 years in scleroderma lung disease. Am J Respir Crit Care Med 2007, 176:1026-1034.

10. Milano A, Pendergrass SA, Sargent JL, George LK, McCalmont TH, Connolly MK, Whitfield ML: Molecular subsets in the gene expression signatures of scleroderma skin. PLOS One 2008, 3:e2696.

11. Dees C, Akhmetshina A, Zerr P, Reich N, Palumbo K, Horn A, Jüngel A, Beyer C, Krönke G, Zwerina J, Reiter R, Alenina N, Maroteaux L, Gay S, Schett G, Distler O, Distler JH: Platelet-derived serotonin links vascular disease and tissue fibrosis. J Exp Med 2011, 208:961-972.

12. Koch $A E$, Distler O: Vasculopathy and disordered angiogenesis in selected rheumatic diseases: rheumatoid arthritis and systemic sclerosis. Arthritis Res Ther 2007, 9(Suppl 2):S3.

13. Stachów A, Jabłońska S, Skiendzielewska A: Biogenic amines derived from tryptophan in systemic and cutaneous scleroderma. Acta Derm Venereol 1979, 59:1-5.

14. Biondi ML, Marasini B, Bianchi E, and Agostoni A: Plasma free and intraplatelet serotonin in patients with Raynaud's phenomenon. Int $\mathrm{J}$ Cardiol 1988, 19:335-339.

15. Hervé $P$, Launay JM, Scrobohaci ML, Brenot G, Simonneau G, Petitpretz P, Poubeau P, Cerrina J, Duroux P, Drouet L: Increased plasma serotonin in primary pulmonary hypertension. Am J Med 1995, 99:249-254.

16. Varga J, Abraham D: Systemic sclerosis: a prototypic multisystem fibrotic disorder. J Clin Invest 2007, 117:557-567.

17. Goldberg SC, Halmi KA, Eckert ED, Casper RC, Davis JM: Cyproheptadine in anorexia nervosa. Br J Psychiatry 1979, 134:67-70.

18. Bonhaus DW, Bach C, DeSouza A, Salazar FH, Matsuoka BD, Zuppan P, Chan HW, Eglen RM: The pharmacology and distribution of human 5hydroxytryptamine $2 \mathrm{~B}(5-\mathrm{HT} 2 \mathrm{~B})$ receptor gene products: comparison with 5-HT2A and 5-HT2C receptors. Br J Pharmacol 1995, 115:622-628.

19. Glusa $\mathrm{E}$, Pertz $\mathrm{HH}$ : Further evidence that 5-HT-induced relaxation of pig pulmonary artery is mediated by endothelial $5-\mathrm{HT}(2 \mathrm{~B})$ receptors. $\mathrm{Br} J$ Pharmacol 2000, 130:692-698.

20. Jähnichen S, Horowski R, Pertz HH: Agonism at 5-HT2B receptors is not a class effect of the ergolines. Eur J Pharmacol 2005, 513:225-228.
21. Beyer C, Schett G, Distler O, Distler JH: Animal models of systemic sclerosis: prospects and limitations. Arthritis Rheum 2010, 62:2831-2844.

22. Distler JH, Distler O: Criteria to select molecular targets for anti-fibrotic therapy. Rheumatology 2008, 47(Suppl 5):v12-3.

23. Walther DJ, Peter JU, Winter S, Höltje M, Paulmann N, Grohmann M, Vowinckel J, Alamo-Bethencourt V, Wilhelm CS, Ahnert-Hilger G, Bader M: Serotonylation of small GTPases is a signal transduction pathway that triggers platelet alpha-granule release. Cell 2003, 115:851-862.

doi:10.1186/1755-1536-5-S1-S19

Cite this article as: Iwamoto and Distler: Molecular targets for therapy in systemic sclerosis. Fibrogenesis \& Tissue Repair 2012 5(Suppl 1):S19.

\section{Submit your next manuscript to BioMed Central and take full advantage of:}

- Convenient online submission

- Thorough peer review

- No space constraints or color figure charges

- Immediate publication on acceptance

- Inclusion in PubMed, CAS, Scopus and Google Scholar

- Research which is freely available for redistribution 